\title{
Lingering illness or sudden death? Pre-exit employment developments in German establishments
}

\author{
Daniel Fackler*, Claus Schnabel** and Joachim Wagner ${ }^{\dagger, *}$
}

\begin{abstract}
Using a large administrative data set for Germany, this article compares employment developments in exiting and surviving establishments. Applying a matching approach, we find a clear "shadow of death" effect reflecting lingering illness: in both West and East Germany establishments shrink dramatically already several years before closure, employment growth rates differ strongly between exiting and surviving establishments, and this difference becomes stronger as exit approaches. Moreover, we provide first evidence that prior to exit the workforce becomes on average more skilled, more female, and older in exiting compared to surviving establishments. These effects are more clearly visible in West than in East Germany.
\end{abstract}

JEL classification: L2, D22, J65.

\section{Introduction}

Although firm closures are important drivers of structural change and economic development, they are unpleasant for all parties involved-be they employees, management, investors, banks, suppliers, or customers. Therefore, these agents are interested to know how likely a firm is to survive, what determines firm exits, and whether there is a "shadow of death" visible already some time before a firm finally

\footnotetext{
${ }^{\star}$ Daniel Fackler, University of Erlangen-Nürnberg, Chair of Labour and Regional Economics, Lange Gasse 20, 90403 Nürnberg, Germany. e-mail: daniel.fackler@wiso.uni-erlangen.de

${ }^{\star *}$ Claus Schnabel, University of Erlangen-Nürnberg, Chair of Labour and Regional Economics, Lange Gasse 20, 90403 Nürnberg, Germany. e-mail: claus.schnabel@wiso.uni-erlangen.de

†Joachim Wagner, Leuphana University Lüneburg, Institute of Economics, PO Box 2440, 21314 Lüneburg, Germany. e-mail: Wagner@leuphana.de
}

\$Main author for correspondence. 
closes down, thus making preventive actions possible. Although there is some literature on the determinants of firm exits (e.g., Disney et al., 2003 for the UK; Bernard and Jensen, 2007 for the United States; Bellone et al., 2008 for France; Box, 2008 for Sweden; Esteve-Pérez and Mañez-Castillejo, 2008 for Spain; Fackler et al., 2013 for Germany), much less is known about the processes taking place before closure. In order to fill this research gap, this article analyzes whether firm closures occur suddenly and unexpectedly or whether employment processes can be observed that indicate an upcoming closure. This is important to know for several reasons. If firms typically suffer sudden deaths, possibilities to prevent these would be very limited, and the resulting layoffs are likely to be mass layoffs creating particularly serious problems for employees and employment agencies. In contrast, if firms usually show a lingering illness before finally exiting, falls in employment can be expected to be much smoother, spreading over several years. Such a process of gradual employment reduction in turn may be a valuable signal of an upcoming closure and might thus improve the prospects of taking measures that help to prevent firm failure.

In this article, we particularly address two research questions: Do changes in overall employment differ between exiting and surviving establishments? And, more specifically, does the composition of the workforce in terms of skill level, gender, and age develop differently in exiting and surviving establishments? In analyzing these questions, our article makes two major contributions to the literature: First, as we have a very large representative data set containing $50 \%$ of all establishments in Germany and covering the period 1975-2008, we are able to study employment trends preceding exits in much greater detail than previously possible. Second, we investigate how the composition of the workforce develops prior to firm closure. Concerning changes in the gender and age structure of the workforce, to the best of our knowledge, no comparison of exiting and surviving firms does exist, and concerning changes in the skill structure, we are the first ones to examine this for Germany.

As mentioned above, there is not much literature focusing on pre-exit developments. An early paper by Hambrick and D'Aveni (1988) compares 57 large bankruptcies with 57 matched survivors. The authors find that a poorer performance in failing firms shows up very early. Based on their findings they conclude that at least in large companies there should be options to prevent failure. Studying productivity dynamics in Israeli industry, Griliches and Regev (1995) report that exiting firms are less productive than surviving firms already several years before they finally exit. This is what they call a "shadow of death" effect. The existence of such an effect in terms of declining productivity is confirmed by several other studies (Bellone et al., 2006 for France; Kiyota and Takizawa, 2006 for Japan; Carreira and Teixeira, 2011 for Portugal). Examining firms' adjustment processes for the United States (Wisconsin), Troske (1996) finds that employment growth and the firm size relative to industry average decline before exit. Similar results suggesting that firms tend to shrink before 
closure are obtained by Bellone et al. (2006) for France and Huynh and Petrunia (2011) for Canada. ${ }^{1}$

For Germany there are three studies on the "shadow of death" effect. Wagner (1999) examines three exit cohorts of manufacturing firms in the federal state of Lower Saxony. He finds that declining employment can be observed only for a relatively small fraction of all exits and that there is no significant relationship between productivity and the probability of exit which makes him conclude that there is no "shadow of death" effect. By contrast, empirical evidence for the federal state of Saxony by Niese (2003) shows that there is a negative relationship between productivity and the probability of exit already 3 years before closure. Additionally, he finds a negative relationship between both employment and productivity growth and the probability of exit, which is in favor of a "shadow of death" effect.

The study which is closest to ours is by Almus (2004). Using 1765 observations from a telephone survey and applying a matching approach, he analyzes employment growth of exiting versus surviving firms for the period 1990-1999. He finds declining employment levels and significantly lower growth rates in exiting firms up to 3 years before closure, confirming the existence of a "shadow of death" effect. However, the study considers only the entry cohorts of 1990-1993 and thus focuses on relatively young firms. As our data set contains a substantially larger and more representative sample and covers a much longer time period than Almus (2004), we will be able to provide more comprehensive evidence on the "shadow of death."

Our second research question, how the composition of the workforce develops before exit, is particularly interesting since a "shadow of death" effect in terms of declining employment may reflect two different reactions to economic distress by management and employees. Declining employment can on the one hand be interpreted as a downward adjustment of the employment level initiated by firm management trying to prevent closure. On the other hand, employees of distressed firms may be induced to look for other jobs and leave the firm if possible. If the first effect is dominant, we would expect the composition of the workforce to become more skilled before closure since the management may try to get rid of the least productive workers (or those who are most easily dispensable) first. A similar result could show up if it is primarily the (usually highly skilled) management staff that stays until the end in order to manage the process of closure. If the second effect dominates, we would expect that the workforce becomes less skilled since those workers with the best labor market opportunities, that is, the more skilled ones, are likely to leave first whereas less skilled workers are more likely to stay until the end (Lengermann and Vilhuber, 2002; Schwerdt, 2011). Of course, such a loss of

\footnotetext{
${ }^{1}$ Some studies also take account of further indicators besides productivity and firm size. Bellone et al. (2006) additionally find declining relative profitability before exit. Huynh and Petrunia (2011) mainly focus on the development of financial indicators. Their main finding is that leverage increases before exit.
} 
human capital can additionally worsen a firm's situation and speed up the exit process. Empirically, Schwerdt (2011) finds for Austria that workers leaving dying firms already before closure experience better post-separation outcomes, that is, higher employment probabilities and earnings, suggesting that these workers are more productive than those staying until the end. For the United States (Maryland), Lengermann and Vilhuber (2002) also report that the composition of the workforce becomes less skilled before large displacements occur. Both studies thus imply that the second effect is more important. ${ }^{2}$

Like the skill composition, the gender composition of the workforce may also change as exit approaches, and this again can reflect various reactions by employees and management. Taking the perspective of employees first, women may be less inclined than men to leave firms in distress. They usually face higher search frictions and are less mobile than men, not least due to family reasons, and there is some empirical evidence that women's labor supply to the firm is substantially less elastic than men's (see Manning, 2003 and Hirsch et al., 2010). In contrast, management may find it easier to lay off women than men since they often have less tenure and firm-specific human capital. If women have less tenure and are secondary wage earners, they also enjoy a lesser degree of actual employment protection in Germany. Depending on the relative strength of these opposite effects, the share of women in the workforce may either rise or fall prior to firm exit.

A third characteristic of the workforce that may also change as exit approaches is the age structure. From the view of employees, older workers have fewer incentives to leave distressed firms. They usually have more tenure and, therefore, more firmspecific human capital that would be worthless in other firms, and their labor market opportunities may be worse than those of younger workers. From the perspective of management, the case for retaining older employees in times of distress is more ambiguous. On the one hand, older workers are more likely to be kept in the firm because of their experience and specific knowledge and because lay-offs of older employees are usually more difficult and costly due to employment protection laws. On the other hand, older workers may be less flexible and, therefore, not the right ones to successfully implement changes in a firm's strategy designed to prevent closure. Moreover, laying off older employees may relieve firms from the "burden" of high seniority wages. Depending on the relative strength of these different effects, the average age of the workforce may either rise or fall prior to firm exit. Which of these effects dominates is an open question.

\footnotetext{
${ }^{2}$ Using a model of two-sided learning where management and employees learn about each other's behavior, Pfann and Hamermesh (2008) analyze employment developments, quits, and layoffs at Fokker Aircraft, a large Dutch firm, during its last 6 years of existence. They find, inter alia, that these last years were characterized by declining employment and that those workers who stayed until the end seemed to be more valuable for the firm (in that they had more tenure, better job evaluations, and more internal training courses than those leaving the firm).
} 
In the following analysis, we address these considerations empirically proceeding as follows. Section 2 describes our data set and the procedure to identify firm exits. In Section 3, the empirical approach is explained, and the results are presented in Section 4. Section 5 concludes.

\section{Data and identification of exits}

For the following analysis we use the German Establishment History Panel (BHP), a large and representative administrative data set provided by the Research Data Centre of the Federal Employment Agency at the Institute for Employment Research. The BHP contains a random sample of $50 \%$ of all establishments with at least one employee liable to social security and currently covers the period 1975-2008 for West Germany and 1991-2008 for East Germany, but because of the bad data quality in East Germany shortly after reunification it is recommended to use the East German data only from 1993 onwards (Hethey-Meier and Seth, 2010: 8). The data are annual and reflect the situation in the establishment on June 30 of each year. They are created by aggregating the underlying social security data_the "Employee and Benefit Recipient History" (BLH) — at the establishment level. The BHP contains information on industry, ${ }^{3}$ location, number of employees, composition of the workforce, and wage structure (for more detailed information, see Spengler, 2008; Hethey-Meier and Seth, 2010). Major advantages of the BHP compared to other data sets are that it covers all industries and a longer time span and that it can be considered very reliable as it is based on mandatory social security announcements.

Since every establishment is allocated a unique identification number that normally does not change, we are able to follow establishments over time. Generally we regard establishments as exits in that year when they appear in the data for the last time, that is, when for the last time they report having employees who are liable to social security. ${ }^{4}$ Analogously, establishments are considered to be entries in the year when they first appear in the data. ${ }^{5}$

Identifying entries and exits only based on newly appearing or disappearing establishment numbers has an important shortcoming: events like changes of

\footnotetext{
${ }^{3}$ Since there are breaks in the industry classification, a time-consistent industry classification variable based on the procedure by Eberle et al. (2011) was provided by the Research Data Center.

${ }^{4}$ Since establishments disappear from the data set when they stop having employees liable to social security, exit might have occurred later than recorded in the data. Similarly, entry could have occurred earlier. As we are mainly interested in establishments' employment history, these shortcomings do not affect our investigation.

${ }^{5}$ For establishments that already appear in the data in 1975 we do not know whether they entered in 1975 or earlier, which means that we also do not know their exact age.
} 
ownership or legal form, outsourcing, or other administrative changes can result in a change of the establishment number, which would lead to an overestimation of the number of entries and exits. ${ }^{6}$ To solve this problem, we use extension files on establishment histories provided by the Research Data Center that are based on the work by Hethey and Schmieder (2010) who analyze worker flows between establishment numbers in the underlying personal-level data. ${ }^{7}$ They use maximum clustered in- and outflows, that is, the largest groups of workers switching from one establishment number to another, to classify newly appearing and disappearing establishment numbers into seven categories each. This procedure enables researchers to discriminate between true entries and exits and other events causing a change of the establishment number. Concerning the identification of exits, if establishment A exits in period $t$ and more than $80 \%$ of that establishment's workforce is employed in establishment $\mathrm{B}$ in $t+1$, it is likely that establishment $\mathrm{A}$ does not cease to exist. Depending on whether B is a new or an existing establishment, the disappearance of establishment A is regarded as "ID change" or "takeover," respectively. In some cases, a meaningful interpretation is not possible. These cases, which are labeled "unclear" by Hethey and Schmieder (2010), are excluded from our sample. A more detailed description how these extension files are used to identify true exits is provided by Fackler et al. (2013). ${ }^{8}$

Our sample is restricted to the private sector, that is, the public sector and other nonprofit sectors are excluded from the analysis. We further exclude the agriculture and the mining sector because exits in these sectors are strongly subject to political influence (e.g., subsidization, downsizing plans of the European Union).

\section{Empirical approach}

In the following, we analyze employment developments of exiting establishments in their last 5 years of existence and compare them with surviving establishments. We only look at establishments that are at least 5 years old. This ensures that our

\footnotetext{
${ }^{6}$ For a more detailed discussion of the problems concerning the identification of entries and exits see Brixy and Fritsch (2002).

${ }^{7}$ Since 1999 marginal part-time workers are included in the BLH and, therefore, also in our BHP data set. For time consistency, those employment relationships were dropped in the analysis of Hethey and Schmieder (2010) that makes use of personal-level data. For the identification of establishments' entries and exits we follow their approach. However, as we do not have access to the worker-level data, we are not able to construct a fully time-consistent data set, for example, by calculating employment shares without marginal part-time workers in the numerator. Nevertheless, we decided not to exclude all establishments with marginal workers from our sample.

${ }^{8}$ We also ran robustness checks applying different classifications of exits which did not affect our main insights.
} 
comparison of exiting and surviving establishments is not affected by establishments that enter the two groups during the last 5 years. Survivors are defined as establishments that continue to exist for at least 5 years. This is to make sure that we do not compare exits with other establishments that are already in serious distress and may also exit soon. The period of exit, that is, when establishments are ultimately observed before exiting, is denoted $t$. For survivors $t$ is any period in which the respective establishment is at least 5 years old and continues to exist for at least 5 years. This procedure restricts the following analysis to the exit cohorts 1980-2003 for West Germany and 1998-2003 for East Germany. ${ }^{9}$

Since the employment growth rates and employment shares that are calculated for the following analyses would be rather meaningless measures for very small establishments, we restrict our analysis to establishments with at least 10 employees in $t-5$ (i.e., 5 years before they are observed for the last time) in order to obtain results that can be interpreted in a meaningful manner. As most exiting establishments are small, this leads to a considerable reduction of the relevant sample (by about 75\%). To make sure that the results are not mainly driven by this constraint, we also conducted the same analyses without this restriction which made the relevant effects appear less pronounced but did not change our main insights. ${ }^{10}$

As employment developments taking place before closure could partially be driven by the fact that exiting and surviving establishments differ with respect to other relevant characteristics, we apply a propensity score matching approach to control for numerous observable characteristics (see e.g., Caliendo and Kopeinig, 2008). This enables us to construct a group of survivors whose characteristics are as similar as possible to those of the exiting establishments 5 years prior to firm closure. We perform one-to-one nearest neighbor matching without replacement using the Stata module PSMATCH2 by Leuven and Sianesi (2003). To compute the propensity score a probit regression is estimated with the dependent variable being one for exits and zero for survivors. ${ }^{11}$ As covariates we include the logarithm of the number of employees in $t-5$ as a third order polynomial, the workforce composition in $t-5$ (the shares of low qualified employees, skilled occupations, highly skilled occupations, females, and the median age), dummies for two-digit industry, year, year of entry, type of entry (according to the classification by Hethey and Schmieder, 2010)

\footnotetext{
${ }^{9}$ Since considering only the last 5 years might appear quite arbitrary, we ran a robustness check analyzing exits in the last 10 years of existence. Correspondingly, we chose only establishments that were at least 10 years old in period $t$ and defined survivors as continuing for at least 10 years. This could be done for the exit cohorts 1985-1998 for West Germany, whereas it was not feasible for East Germany. Running this robustness check did not alter our main insights.

${ }^{10}$ The results of this robustness check can be found in the Appendix.

${ }^{11}$ Our results do not change when we use a complementary log-log model for estimating the propensity score.
} 
and regional dummies (30 administrative districts in West Germany and 8 in East Germany). ${ }^{12}$

Means of selected variables for exits and survivors before and after matching are presented in Table 1a (West Germany) and 1b (East Germany). To get an impression of the matching quality, these tables also show the standardized bias in percent, the percentage reduction of the absolute bias through matching as well as $t$-tests to see whether there remain significant differences in the means for both groups after matching. Caliendo and Kopeinig (2008) state that a standardized bias below 3 or $5 \%$ can be regarded as sufficient.

The statistics in Table 1a and 1b suggest that the covariates listed are well balanced after matching. A standardized bias below 3\% is achieved for all variables in both West and East Germany and the $t$-tests show that no significant differences between exits and survivors remain after matching. Largely the same applies to the variables not listed in Table 1a and $1 \mathrm{~b}$ (such as year, region, and industry). Only in very few

Table 1a Balancing of selected variables before and after matching, West Germany

\begin{tabular}{|c|c|c|c|c|c|c|}
\hline \multirow[t]{2}{*}{ Variable (in $t-5$ ) } & \multirow[t]{2}{*}{ Sample } & \multicolumn{2}{|l|}{ Mean } & \multirow{2}{*}{$\begin{array}{l}\text { Standardized } \\
\text { bias (\%) }\end{array}$} & \multirow{2}{*}{$\begin{array}{l}\text { Reduction } \\
\text { of absolute } \\
\text { bias (\%) }\end{array}$} & \multirow{2}{*}{$\begin{array}{l}t \text {-test } \\
\text { (difference } \\
\text { in means) }\end{array}$} \\
\hline & & Exits & Survivors & & & \\
\hline \multirow[t]{2}{*}{ Number of employees } & Unmatched & 38.147 & 61.864 & -7.8 & & $-14.11 * * *$ \\
\hline & Matched & 38.147 & 37.849 & 0.1 & 98.7 & 0.56 \\
\hline Low-qualified & Unmatched & 24.748 & 25.426 & -3.0 & & $-7.53^{* * *}$ \\
\hline employees (\%) & Matched & 24.748 & 24.696 & 0.2 & 92.2 & 0.40 \\
\hline Skilled & Unmatched & 50.072 & 52.959 & -9.1 & & $-22.45^{* * *}$ \\
\hline occupations (\%) & Matched & 50.072 & 50.045 & 0.1 & 99.0 & 0.15 \\
\hline Highly skilled & Unmatched & 5.055 & 5.723 & -5.4 & & $-12.62^{* * *}$ \\
\hline occupations (\%) & Matched & 5.055 & 5.029 & 0.2 & 96.1 & 0.40 \\
\hline \multirow[t]{2}{*}{ Females (\%) } & Unmatched & 37.035 & 36.298 & 2.4 & & $6.03^{* * *}$ \\
\hline & Matched & 37.035 & 37.159 & -0.4 & 83.2 & -0.70 \\
\hline \multirow[t]{2}{*}{ Median age (years) } & Unmatched & 35.204 & 34.188 & 13.7 & & $34.37^{* * *}$ \\
\hline & Matched & 35.204 & 35.215 & -0.1 & 99.0 & -0.25 \\
\hline
\end{tabular}

Notes: Exit cohorts 1980-2003, private sector without agriculture and mining, establishments with at least 10 employees in $t-5,{ }^{* * *} / * * / *$ indicates statistical significance at the $1 \% / 5 \% / 10 \%$ level.

\footnotetext{
${ }^{12}$ In an earlier version of this article (Fackler et al., 2012), we only allowed for matches within the same year and two-digit industry. This approach worsened the matching quality with respect to some other covariates without affecting our insights.
} 
Table 1b Balancing of selected variables before and after matching, East Germany

\begin{tabular}{|c|c|c|c|c|c|c|}
\hline \multirow[t]{2}{*}{ Variable (in $t-5$ ) } & \multirow[t]{2}{*}{ Sample } & \multicolumn{2}{|l|}{ Mean } & \multirow{2}{*}{$\begin{array}{l}\text { Standardized } \\
\text { bias (\%) }\end{array}$} & \multirow{2}{*}{$\begin{array}{l}\text { Reduction } \\
\text { of absolute } \\
\text { bias (\%) }\end{array}$} & \multirow{2}{*}{$\begin{array}{l}t \text {-test } \\
\text { (difference } \\
\text { in means) }\end{array}$} \\
\hline & & Exits & Survivors & & & \\
\hline \multirow[t]{2}{*}{ Number of employees } & Unmatched & 31.231 & 35.400 & -5.1 & & $-3.31 * * *$ \\
\hline & Matched & 31.231 & 32.272 & -1.3 & 75.0 & -0.68 \\
\hline \multirow{2}{*}{$\begin{array}{l}\text { Low-qualified } \\
\text { employees (\%) }\end{array}$} & Unmatched & 10.822 & 10.881 & -0.4 & & -0.26 \\
\hline & Matched & 10.822 & 10.897 & -0.5 & -26.0 & -0.24 \\
\hline \multirow{2}{*}{$\begin{array}{l}\text { Skilled } \\
\text { occupations (\%) }\end{array}$} & Unmatched & 51.337 & 49.112 & 6.5 & & $4.64^{* * *}$ \\
\hline & Matched & 51.337 & 51.338 & -0.0 & 100.0 & -0.00 \\
\hline \multirow{2}{*}{$\begin{array}{l}\text { Highly skilled } \\
\text { occupations (\%) }\end{array}$} & Unmatched & 6.985 & 9.325 & -14.1 & & $-9.18^{* * *}$ \\
\hline & Matched & 6.985 & 6.604 & 2.3 & 83.7 & 1.35 \\
\hline \multirow[t]{2}{*}{ Females (\%) } & Unmatched & 28.948 & 37.097 & -26.5 & & $-18.17^{* * *}$ \\
\hline & Matched & 28.948 & 28.704 & 0.8 & 97.0 & 0.43 \\
\hline \multirow[t]{2}{*}{ Median age (years) } & Unmatched & 35.809 & 35.787 & 0.4 & & 0.26 \\
\hline & Matched & 35.809 & 35.856 & -0.8 & -109.1 & -0.41 \\
\hline
\end{tabular}

Notes: Exit cohorts 1998-2003, private sector without agriculture and mining, establishments with at least 10 employees in $t-5,{ }^{* * *} / * * / *$ indicates statistical significance at the $1 \% / 5 \% / 10 \%$ level.

cases a standardized bias above 3\% (but still below 5\%) is found, and no statistically significant differences show up at the $5 \%$ resp. $1 \%$ level. The matching procedure can therefore be regarded as successful.

\section{Results}

We start our analysis by comparing employment growth of exiting and surviving establishments. ${ }^{13}$ Average employment growth rates for these two groups are presented in Table 2. For both East and West Germany, one can see that employment growth rates are negative for exiting establishments in all 5 years before closure and that this employment reduction becomes stronger as exit approaches, culminating in an employment reduction by about $40 \%$ in the last period. Comparing exits and survivors shows that employment growth rates differ significantly between both groups in all periods and that the difference becomes larger as exit approaches, reaching almost 40 percentage points in the last period. This evidence points to a

13 As proposed by Davis and Haltiwanger (1999: 2718f), the employment growth rate $g$ for establishment $i$ between two periods $t$ and $t-1$ is calculated by $g_{i, t}=\left(\mathrm{emp}_{i, t}-\mathrm{emp}_{i, t-1}\right)$ / $\left(0.5^{\star}\left(\mathrm{emp}_{i, t}+\mathrm{emp}_{i, t-1}\right)\right)$. 
Table 2 Employment growth rates for exiting versus surviving establishments (in percent), matched sample

\begin{tabular}{|c|c|c|c|c|c|c|}
\hline \multirow[t]{2}{*}{ Period } & \multicolumn{3}{|c|}{ West Germany } & \multicolumn{3}{|c|}{ East Germany } \\
\hline & Exits & Survivors & Difference & Exits & Survivors & Difference \\
\hline$t, t-1$ & -40.35 & -0.49 & $-39.86^{* * *}$ & -39.98 & -3.82 & $-36.16^{* * *}$ \\
\hline$t-1, t-2$ & -12.69 & 0.20 & $-12.89^{* * *}$ & -15.46 & -2.53 & $-12.93 * * *$ \\
\hline$t-2, t-3$ & -7.54 & 0.54 & $-8.09 * * *$ & -9.31 & -1.65 & $-7.66^{* * *}$ \\
\hline$t-3, t-4$ & -5.15 & 0.81 & $-5.96^{* * *}$ & -5.46 & 0.28 & $-5.74^{* * *}$ \\
\hline$t-4, t-5$ & -4.16 & 0.13 & $-4.30^{* * *}$ & -3.65 & 2.87 & $-6.52^{* * *}$ \\
\hline Obs. & 62,674 & 62,674 & - & 5,401 & 5,401 & - \\
\hline
\end{tabular}

Notes: West Germany 1980-2003, East Germany 1998-2003, private sector without agriculture and mining, establishments with at least 10 employees in $t-5,{ }^{* * *} / * * / *$ indicates statistical significance at the $1 \% / 5 \% / 10 \%$ level.

strong and long lasting "shadow of death" effect which is in line with previous empirical evidence outlined in Section 1. Additional support for this effect is obtained when we look at those establishments where the number of employees did not increase in any of the 5 years before closure: This phenomenon is found in $17 \%$ of all exiting firms but only in $6 \%$ of all survivors in our West German sample. A similar picture shows up for East Germany where the corresponding rates are $15 \%$ of the exits and only $8 \%$ of the survivors.

In a next step, we analyze how the qualification structure develops before closure, making use of three different indicators. The first is the percentage share of lowqualified employees in the workforce, that is, those who do not have an upper secondary school leaving certificate as their highest school qualification or do not have a vocational qualification. The other two indicators reflect the occupational status of employees: they are the shares of skilled occupations (skilled manual occupations, skilled services, skilled commercial and administrative occupations, technicians) and of highly skilled occupations (semiprofessions, engineers, professions, managers) calculated according to the Blossfeld (1987) occupational classification (see also Hethey-Meier and Seth, 2010).

Table 3 shows changes of these three indicators in percentage points for exiting and surviving establishments over the 5 years observed. For West Germany, it can be seen that the share of low-qualified employees decreases slightly for both exits and survivors. For exiting establishments, this effect is significantly stronger in the last four periods before closure, and the difference becomes larger as death approaches. 
Table 3 Changes in the employment structure for exiting versus surviving establishments (in percentage points), matched sample

\begin{tabular}{|c|c|c|c|c|c|c|}
\hline \multirow[t]{2}{*}{ Period } & \multicolumn{3}{|c|}{ West Germany } & \multicolumn{3}{|c|}{ East Germany } \\
\hline & Exits & Survivors & Difference & Exits & Survivors & Difference \\
\hline & \multicolumn{6}{|c|}{ Low-qualified employees } \\
\hline$t, t-1$ & -1.71 & -0.37 & $-1.33^{* * *}$ & -0.21 & -0.42 & 0.22 \\
\hline$t-1, t-2$ & -0.66 & -0.35 & $-0.31 * * *$ & -0.38 & -0.33 & -0.05 \\
\hline$t-2, t-3$ & -0.51 & -0.37 & $-0.14^{* * *}$ & 0.01 & 0.12 & -0.11 \\
\hline$t-3, t-4$ & -0.48 & -0.33 & $-0.15^{* * *}$ & 0.30 & 0.24 & 0.07 \\
\hline \multirow[t]{2}{*}{$t-4, t-5$} & -0.44 & -0.34 & $-0.10^{* *}$ & 0.52 & 0.48 & 0.04 \\
\hline & \multicolumn{6}{|c|}{ Skilled occupations } \\
\hline$t, t-1$ & 1.16 & -0.02 & $1.18^{* * *}$ & 0.44 & -0.06 & $0.50^{*}$ \\
\hline$t-1, t-2$ & 0.16 & -0.02 & $0.18^{* * *}$ & 0.05 & 0.00 & 0.05 \\
\hline$t-2, t-3$ & 0.08 & -0.05 & $0.13^{* *}$ & 0.07 & 0.08 & -0.01 \\
\hline$t-3, t-4$ & 0.03 & -0.04 & 0.07 & 0.07 & -0.16 & 0.24 \\
\hline \multirow[t]{2}{*}{$t-4, t-5$} & 0.06 & 0.06 & 0.01 & 0.28 & -0.07 & $0.35 * *$ \\
\hline & \multicolumn{6}{|c|}{ Highly skilled occupations } \\
\hline$t, t-1$ & 0.89 & 0.02 & $0.87 * * *$ & 0.79 & -0.03 & $0.82 * * *$ \\
\hline$t-1, t-2$ & 0.24 & -0.01 & $0.25^{* * *}$ & 0.22 & 0.00 & $0.22^{*}$ \\
\hline$t-2, t-3$ & 0.12 & -0.02 & $0.14^{* * *}$ & -0.00 & -0.02 & 0.02 \\
\hline$t-3, t-4$ & 0.07 & -0.03 & $0.10 * * *$ & -0.02 & -0.06 & 0.04 \\
\hline \multirow[t]{2}{*}{$t-4, t-5$} & 0.03 & -0.01 & $0.04^{* *}$ & -0.00 & -0.02 & 0.02 \\
\hline & \multicolumn{6}{|c|}{ Females } \\
\hline$t, t-1$ & 1.97 & 0.18 & $1.80 * * *$ & 1.57 & 0.37 & $1.20 * * *$ \\
\hline$t-1, t-2$ & 0.47 & 0.24 & $0.23^{* * *}$ & 0.66 & 0.37 & 0.29 \\
\hline$t-2, t-3$ & 0.35 & 0.25 & $0.10^{* *}$ & 0.31 & 0.47 & -0.17 \\
\hline$t-3, t-4$ & 0.37 & 0.27 & $0.10 * *$ & 0.42 & 0.44 & -0.02 \\
\hline$t-4, t-5$ & 0.33 & 0.27 & $0.06^{*}$ & 0.53 & 0.30 & $0.22 *$ \\
\hline Obs. & 62,674 & 62,674 & - & 5,401 & 5,401 & - \\
\hline
\end{tabular}

Notes: West Germany 1980-2003, East Germany 1998-2003, private sector without agriculture and mining, establishments with at least 10 employees in $t-5, * * * / * * *$ indicates statistical significance at the $1 \% / 5 \% / 10 \%$ level.

Between $t$ and $t-1$, for instance, the share of low-qualified employees falls by 1.7 percentage points in exiting establishments whereas it decreases by only 0.4 percentage points in surviving establishments. Having in mind that employment reductions prior to exit can reflect reactions by management trying to get rid of less productive workers and by (skilled) employees looking for other jobs, the fact that the 
share of low-qualified employees decreases more strongly in exiting establishments suggests that the first effect slightly dominates. A corresponding picture emerges by looking at the development of the shares of skilled and highly skilled occupations. Both shares stay relatively constant in surviving establishments, whereas they become increasingly larger in exiting establishments as death approaches. In contrast to Schwerdt (2011) and Lengermann and Vilhuber (2002), our evidence therefore suggests that the composition of the workforce becomes more skilled before closure.

For East Germany the picture is not that clear. Looking at the development of the share of low-qualified employees, systematic differences between exits and survivors before an upcoming closure cannot be observed. However, the shares of skilled and highly skilled occupations increase more strongly in exiting establishments and the difference is statistically significant in the last (resp. the last two) periods before closure. This also tends to support the view that the workforce composition becomes more skilled as exit approaches.

The finding that the average skill level of the workforce increases before exit might reflect that some (skilled or highly skilled) management staff needs to stay until the end in order to manage the process of closure. To test this potential explanation we analyzed the development of the share of managers (who are part of our category of highly skilled occupations) and the share of skilled commercial and administrative occupations (such as bookkeepers or financial assistants, who belong to our category of skilled occupations and could also partly be attributed to the management staff). The results which are presented in Appendix Table A1 indicate that both shares increase more strongly in exiting establishments and that the increasing average skill level before closure is at least partly driven by the management staying on board until the end. ${ }^{14}$

The lowest panel of Table 3 presents percentage point changes in the shares of females in the workforce over the 5 years observed. Both for West and East Germany we can see that the share of women increases slightly for both exits and survivors. For West Germany, this effect is always stronger in exiting establishments and the difference becomes larger as death approaches, being most pronounced in the last two periods. For East Germany, a significantly positive difference appears only in the last period. Nevertheless, these results suggest that women are more likely to remain on board until the ship sinks. They are consistent with the view of new monopsony theory (Manning, 2003) that women face higher search frictions and are less mobile than men mainly due to domestic responsibilities, which would make them less likely to leave distressed firms.

When analyzing how the age structure of the workforce develops prior to exit we look at the median age of the workforce, which should reflect systematic changes of

\footnotetext{
${ }^{14}$ It should be noted that only employees liable to social security are included in our data and that firm owners are therefore not visible. Particularly, in small firms it can be expected that it is the owners themselves who manage the process of exit.
} 
Table 4 Changes in the median age for exiting versus surviving establishments (absolute changes in years), matched sample

\begin{tabular}{|c|c|c|c|c|c|c|}
\hline \multirow[t]{2}{*}{ Period } & \multicolumn{3}{|c|}{ West Germany } & \multicolumn{3}{|c|}{ East Germany } \\
\hline & Exits & Survivors & Difference & Exits & Survivors & Difference \\
\hline$t, t-1$ & 1.14 & 0.38 & $0.77^{* * *}$ & 0.73 & 0.60 & 0.13 \\
\hline$t-1, t-2$ & 0.71 & 0.36 & $0.35^{* * *}$ & 0.79 & 0.58 & $0.21 * * *$ \\
\hline$t-2, t-3$ & 0.57 & 0.38 & $0.19 * * *$ & 0.58 & 0.48 & 0.09 \\
\hline$t-3, t-4$ & 0.54 & 0.36 & $0.18^{* * *}$ & 0.49 & 0.49 & 0.01 \\
\hline$t-4, t-5$ & 0.51 & 0.33 & $0.18^{* * *}$ & 0.53 & 0.45 & 0.08 \\
\hline Obs. & 62,674 & 62,674 & - & 5,401 & 5,401 & - \\
\hline
\end{tabular}

Notes: West Germany 1980-2003, East Germany 1998-2003, private sector without agriculture and mining, establishments with at least 10 employees in $t-5, * * * / * * / *$ indicates statistical significance at the $1 \% / 5 \% / 10 \%$ level.

the age structure. Table 4 shows absolute changes of the median age for exits and survivors. One can see that the median age rises over time for both exiting and surviving establishments which may reflect the demographic change taking place in Germany. For West Germany, this increase in the median age becomes stronger for exits as death approaches whereas it stays relatively constant for survivors. Accordingly, the difference between exits and survivors also becomes larger and is statistically significant in all 5 periods prior to exit. In the last period, for instance, the median age of the workforce increases by 1.1 years in dying establishments whereas it increases by only 0.4 years in surviving establishments. The age effect in East Germany is similar although less pronounced. The median age increases slightly stronger in exiting establishments but the difference is statistically significant only between $t-1$ and $t-2$. These results may reflect that older workers have fewer incentives to leave distressed firms because of their higher tenure and therefore higher wages as well as their worse labor market opportunities. They are also consistent with the view that management refrains from laying off older workers because of their firm-specific human capital and their higher costs of dismissal. In Germany, employment protection laws, collective bargaining agreements, and social plans in case of mass layoffs strongly reduce the management's possibilities to dismiss older workers.

These insights still hold when running several robustness checks. As already mentioned above, our sample is reduced considerably by looking at only establishments with at least 10 employees in $t-5$. We therefore also conducted our analyses without this restriction, although the interpretation of the measures used in this study is 
questionable in this case (as discussed in Section 3). Appendix Tables A2-A4 show that the relevant effects are still visible but are less pronounced. As looking at the last 5 years before exit might appear arbitrary, we also investigated employment developments in the last 10 years, using only establishments that are at least 10 years old in period $t$ and defining survivors as firms that continue to exist for at least 10 years from period $t$ onwards (this check was only possible for West Germany). We further experimented with different exit classifications and restricted our analyses to some cohorts that exited in recession or boom years. Finally, we also ran nonparametric Kolmogorov-Smirnov tests that confirmed the results of our significant $t$-tests for differences in means by rejecting the null hypothesis of equality of distribution functions for the two samples of exits and survivors. The results of those robustness checks not shown in the Appendix are available upon request from the first author.

\section{Conclusions}

Using a large administrative data set, this article has investigated employment developments in German establishments taking place in the last 5 years before closure. We find for both East and West Germany that establishments shrink in all 5 years before they finally exit, that employment growth rates differ substantially between exiting and surviving establishments, and that this difference becomes stronger as exit approaches. This provides evidence for the existence of a so-called "shadow of death" effect, thus extending and generalizing previous evidence for Germany by Almus (2004) who found this shadow to be present up to 3 years before closure in an entry sample of young firms. Hence, establishments typically do not face sudden deaths, and the development of overall employment preceding exit can be better described as a lingering illness.

As a "shadow of death" effect in terms of falling employment may reflect different reactions to economic distress by management and employees, we have further investigated how the composition of the workforce develops in terms of qualification, gender, and age in the years before exit. For West Germany, we find that the workforce becomes more skilled in exiting compared to surviving establishments as exit approaches. For East Germany, most of the empirical results go in the same direction but the differences between exits and survivors are not statistically significant in many cases. Although the picture is less clear for East Germany, it still tends to suggest that the average skill level of the workforce increases prior to exit. These results indicate that the management's reaction of getting rid of less skilled workers seems to be slightly more important than the voluntary quits of skilled employees. Investigating the source of this effect more closely we find some evidence that the increasing skill level before closure is mainly driven by the management staff staying on board until the end. Interestingly, these results are in contrast to existing 
empirical evidence for Austria (Schwerdt, 2011) and the United States (Lengermann and Vilhuber, 2002) who found that the composition of the workforce becomes less skilled prior to exit. This suggests that more research on this topic is needed, ideally using comparable data sets for different countries.

Our analysis further provides first evidence on the development of the gender and the age structure of the workforce in exiting compared to surviving establishments, two issues that (to the best of our knowledge) have not been investigated before. Our results for West Germany clearly show that the share of women rises more in exiting compared to surviving establishment, suggesting that women are less likely than men to leave distressed firms, probably due to higher search frictions as postulated by new monopsony theory (Manning, 2003). Concerning the age structure, we find that the median age increases stronger in exiting than in surviving establishments. The results support the view that is relatively unattractive for older workers to leave distressed firms and that management is less likely to dismiss them (probably due to their higher firm-specific human capital and their better employment protection). Although the picture concerning both the gender and age structure is less clear for East Germany, the results still point in the same direction as those for West Germany.

Our empirical results have some important implications for studies on the relationships between firm size and the probability of exit. Researchers should be aware of the fact that current firm size may be endogenous as firms tend to reduce employment as a response to economic distress that finally leads to closure. The same applies to the relationship between workforce composition and the probability of exit. Furthermore, as mentioned, for example, by Schwerdt (2011), labor turnover before exit should also be taken into account when examining the effects of displacement on labor market outcomes like earnings. The upshot is that it may be misleading to regard firm exits as exogenous shocks that are unrelated to worker characteristics, as it is often assumed in the literature (see e.g., Kletzer, 1998; Farber, 1999).

The fact that usually employment has declined for several years before firms finally exit shows that job losses due to plant closures spread over a longer period of time and, therefore, typically do not culminate in one mass layoff at the end. This implies that excessively declining employment (as well as the development of other indicators that we cannot observe in our data) may serve as a valuable indicator for an upcoming closure.

\section{Acknowledgements}

We would like to thank the German Research Foundation for financial support under the project SCHN 730/5-1 resp. WA 610/5-1 "Firm exits" (Betriebsschließungen) and the team of the Research Data Centre of the Federal Employment Agency at the Institute for Employment Research for their exceptional support and cooperation. We also thank participants in the economic research seminar at the University of 
Erlangen-Nuremberg and two anonymous referees of this journal for constructive comments.

\section{References}

Almus, M. (2004), 'The shadow of death - an empirical analysis of the pre-exit performance of new German firms,' Small Business Economics, 23, 189-201.

Bellone, F., P. Musso, M. Quéré and L. Nesta (2006), 'Productivity and market selection of French manufacturing firms in the nineties,' Revue de L'OFCE, 97, 319-349.

Bellone, F., P. Musso, L. Nesta and M. Quéré (2008), 'Market selection along the firm life cycle,' Industrial and Corporate Change, 17, 753-777.

Bernard, A. B. and J. B. Jensen (2007), 'Firm structure, multinationals, and manufacturing plant deaths,' Review of Economics and Statistics, 89, 193-204.

Blossfeld, H.-P. (1987), 'Labor market entry and the sexual segregation of careers in the Federal Republic of Germany,' American Journal of Sociology, 93, 89-118.

Box, M. (2008), 'The death of firms: exploring the effects of environment and birth cohort on firm survival in Sweden,' Small Business Economics, 31, 379-393.

Brixy, U. and M. Fritsch (2002), 'Die Betriebsdatei der Beschäftigtenstatistik der Bundesanstalt für Arbeit,' in M. Fritsch and R. Grotz (eds), Das Gründungsgeschehen in Deutschland. Physica: Heidelberg, pp. 55-78.

Caliendo, M. and S. Kopeinig (2008), 'Some practical guidance for the implementation of propensity score matching,' Journal of Economic Surveys, 22, 31-72.

Carreira, C. and P. Teixeira (2011), 'The shadow of death: analysing the pre-exit productivity of Portuguese manufacturing firms,' Small Business Economics, 36, 337-351.

Davis, S. J. and J. Haltiwanger (1999), 'Gross job flows,' in O. Ashenfelter and D. Card (eds), Handbook of Labor Economics, Vol. 3B, Elsevier: Amsterdam, pp. 2711-2805.

Disney, R., J. Haskel and Y. Heden (2003), 'Entry, exit and establishment survival in UK Manufacturing,' Journal of Industrial Economics, 51, 91-112.

Eberle, J., P. Jacobebbinghaus, J. Ludsteck and J. Witter (2011), 'Generation of time-consistent industry codes in the face of classification changes - simple heuristic based on the Establishment History Panel (BHP),' FDZ-Methodenreport 5/2011. Nürnberg.

Esteve-Pérez, S. and J. A. Mañez-Castillejo (2008), 'The resource-based theory of the firm and firm survival,' Small Business Economics, 30, 231-249.

Fackler, D., C. Schnabel and J. Wagner (2013), 'Establishment exits in Germany: the role of size and age,' Small Business Economics, 41, 683-700.

Fackler, D., C. Schnabel and J. Wagner (2012), 'Lingering illness or sudden death? Pre-exit employment developments in German establishments,' IZA Discussion Paper No. 7081. Bonn.

Farber, H. S. (1999), 'Mobility and stability: the dynamics of job change in labor markets,' in O. Ashenfelter and D. Card (eds), Handbook of Labor Economics, Vol. 3B, Elsevier: Amsterdam, pp. 2439-2483. 
Griliches, Z. and H. Regev (1995), 'Firm productivity in Israeli industry 1979-1988,' Journal of Econometrics, 65, 175-203.

Hambrick, D. C. and R. A. D’Aveni (1988), 'Large corporate failures as downward spirals,' Administrative Science Quarterly, 33, 1-23.

Hethey, T. and J. F. Schmieder (2010), 'Using worker flows in the analysis of establishment turnover - evidence from German Administrative Data,' FDZ-Methodenreport 6/2010. Nürnberg.

Hethey-Meier, T. and S. Seth (2010), 'The Establishment History Panel (BHP) 1975 - 2008 Handbook Version 1.0.2,' FDZ-Datenreport 4/2010. Nürnberg.

Hirsch, B., T. Schank and C. Schnabel (2010), 'Differences in labor supply to monopsonistic firms and the gender pay gap: an empirical analysis using linked employer-employee data from Germany,' Journal of Labor Economics, 28, 291-330.

Huynh, K. P. and R. J. Petrunia (2011), 'Post-entry struggle for life and pre-exit shadow of death from a financial perspective,' Paper presented at the 11th Comparative Analysis of Enterprise Data \& COST Conference 2012. Nürnberg.

Kiyota, K. and M. Takizawa (2006), 'The shadow of death: pre-exit performance of firms in Japan,' RIETI Discussion Paper Series 06-E-033. Tokyo.

Kletzer, L. G. (1998), 'Job displacement,' Journal of Economic Perspectives, 12(1), 115-136.

Lengermann, P. and L. Vilhuber (2002), 'Abandoning the sinking ship: the composition of worker flows prior to displacement,' LEHD Technical Paper No. TP-2002-11. Suitland, Maryland.

Leuven, E. and B. Sianesi (2003), 'PSMATCH2: Stata module to perform full Mahalanobis and propensity score matching, common support graphing, and covariate imbalance testing, version 4.06,' http://ideas.repec.org/c/boc/bocode/s432001.html.

Manning, A. (2003), Monopsony in Motion: Imperfect Competition in Labor Markets. Princeton University Press: Princeton, NJ.

Niese, M. (2003), Ursachen von Betriebsschließungen. LIT: Münster.

Pfann, G. A. and D. S. Hamermesh (2008), 'Two-sided learning with applications to labor turnover and worker displacement,' Jahrbücher für Nationalökonomie und Statistik, 228, 423-445.

Schwerdt, G. (2011), 'Labor turnover before plant closure: "Leaving the sinking ship" vs. "Captain throwing ballast overboard", Labour Economics, 18, 93-101.

Spengler, A. (2008), 'The Establishment History Panel,' Schmollers Jahrbuch, 128, 501-509.

Troske, K. R. (1996), 'The dynamic adjustment process of firm entry and exit in manufacturing and finance, insurance and real estate,' Journal of Law and Economics, 39, 705-735.

Wagner, J. (1999), 'The life history of cohorts of exits from German Manufacturing,' Small Business Economics, 13, 71-79. 


\section{Appendix}

Table A1 Changes in the shares of managers and skilled commercial and administrative occupations for exiting versus surviving establishments (in percentage points), matched sample

Period

West Germany

Exits Survivors Difference
East Germany

Exits Survivors Difference

\begin{tabular}{lcccrrc}
\hline & \multicolumn{7}{c}{ Managers } \\
$t, t-1$ & 0.77 & 0.00 & $0.77^{* * *}$ & 0.58 & -0.07 & $0.64^{* * *}$ \\
$t-1, t-2$ & 0.18 & -0.02 & $0.20^{* * *}$ & 0.14 & 0.02 & 0.12 \\
$t-2, t-3$ & 0.12 & -0.04 & $0.15^{* * *}$ & -0.07 & 0.01 & -0.08 \\
$t-3, t-4$ & 0.06 & -0.03 & $0.09^{* * *}$ & 0.07 & -0.05 & $0.12^{*}$ \\
$t-4, t-5$ & 0.03 & -0.01 & $0.03^{*}$ & -0.02 & -0.03 & 0.01 \\
& \multicolumn{7}{c}{ Skilled commercial and administrative occupations } \\
$t, t-1$ & 2.32 & 0.18 & $2.14^{* * *}$ & 1.93 & 0.29 & $1.64^{* * *}$ \\
$t-1, t-2$ & 0.55 & 0.21 & $0.34^{* * *}$ & 0.50 & 0.46 & 0.04 \\
$t-2, t-3$ & 0.39 & 0.17 & $0.22^{* * *}$ & 0.31 & 0.43 & -0.12 \\
$t-3, t-4$ & 0.33 & 0.15 & $0.18^{* * *}$ & 0.47 & 0.23 & $0.24^{*}$ \\
$t-4, t-5$ & 0.35 & 0.24 & $0.11^{* * *}$ & 0.57 & 0.34 & $0.23^{* *}$ \\
Obs. & 62,674 & 62,674 & - & 5,401 & 5,401 & - \\
&
\end{tabular}

Notes: West Germany 1980-2003, East Germany 1998-2003, private sector without agriculture and mining, establishments with at least 10 employees in $t-5,{ }^{* * *} /\left.* *\right|^{*}$ indicates statistical significance at the $1 \% / 5 \% / 10 \%$ level.

Table A2 Employment growth rates for exiting versus surviving establishments (in percent), matched sample, all establishments

\begin{tabular}{|c|c|c|c|c|c|c|}
\hline \multirow[t]{2}{*}{ Period } & \multicolumn{3}{|c|}{ West Germany } & \multicolumn{3}{|c|}{ East Germany } \\
\hline & Exits & Survivors & Difference & Exits & Survivors & Difference \\
\hline$t, t-1$ & -14.67 & 1.78 & $-16.44^{* * *}$ & -17.04 & 1.17 & $-18.21^{* * *}$ \\
\hline$t-1, t-2$ & -4.98 & 2.58 & $-7.56^{* * *}$ & -6.95 & 2.09 & $-9.04^{* * *}$ \\
\hline$t-2, t-3$ & -1.95 & 3.59 & $-5.53^{* * *}$ & -3.09 & 4.33 & $-7.43^{* * *}$ \\
\hline$t-3, t-4$ & -0.29 & 4.84 & $-5.12^{* * *}$ & 0.73 & 6.52 & $-5.79 * * *$ \\
\hline$t-4, t-5$ & 1.73 & 7.96 & $-6.23 * * *$ & 5.53 & 12.81 & $-7.28^{* * *}$ \\
\hline Obs. & 433,811 & 433,811 & - & 32,098 & 32,098 & - \\
\hline
\end{tabular}

Notes: West Germany 1980-2003, East Germany 1998-2003, private sector without agriculture and mining, establishments with one or more employees in $t-5,{ }^{* *} / * * / *$ indicates statistical significance at the $1 \% / 5 \% / 10 \%$ level. 
Table A3 Changes in the employment structure for exiting versus surviving establishments (in percentage points), matched sample, all establishments

\begin{tabular}{|c|c|c|c|c|c|c|}
\hline \multirow[t]{2}{*}{ Period } & \multicolumn{3}{|c|}{ West Germany } & \multicolumn{3}{|c|}{ East Germany } \\
\hline & Exits & Survivors & Difference & Exits & Survivors & Difference \\
\hline & \multicolumn{6}{|c|}{ Low-qualified employees } \\
\hline$t, t-1$ & -0.90 & -0.44 & $-0.46^{* * *}$ & -0.39 & -0.26 & -0.12 \\
\hline$t-1, t-2$ & -0.57 & -0.42 & $-0.14^{* * *}$ & -0.12 & -0.19 & 0.07 \\
\hline$t-2, t-3$ & -0.34 & -0.36 & 0.02 & 0.33 & 0.11 & $0.22 * *$ \\
\hline$t-3, t-4$ & -0.47 & -0.23 & $-0.24^{* * *}$ & 0.04 & 0.14 & -0.09 \\
\hline \multirow[t]{2}{*}{$t-4, t-5$} & -0.38 & -0.16 & $-0.22^{* * *}$ & 0.31 & 0.38 & -0.07 \\
\hline & \multicolumn{6}{|c|}{ Skilled occupations } \\
\hline$t, t-1$ & 0.10 & -0.15 & $0.25^{* * *}$ & 0.11 & -0.11 & 0.21 \\
\hline$t-1, t-2$ & -0.13 & -0.13 & 0.01 & -0.28 & -0.29 & 0.01 \\
\hline$t-2, t-3$ & -0.17 & -0.15 & -0.02 & -0.15 & -0.20 & 0.05 \\
\hline$t-3, t-4$ & -0.21 & -0.14 & $-0.07 * *$ & -0.15 & -0.25 & 0.10 \\
\hline \multirow[t]{2}{*}{$t-4, t-5$} & -0.14 & 0.01 & $-0.15^{* * *}$ & -0.04 & 0.11 & -0.15 \\
\hline & \multicolumn{6}{|c|}{ Highly skilled occupations } \\
\hline$t, t-1$ & 0.23 & -0.06 & $0.29 * * *$ & 0.13 & -0.15 & $0.28 * * *$ \\
\hline$t-1, t-2$ & 0.04 & -0.03 & $0.07 * * *$ & -0.01 & -0.16 & $0.15^{* *}$ \\
\hline$t-2, t-3$ & -0.02 & -0.06 & $0.04^{* *}$ & -0.11 & -0.17 & 0.06 \\
\hline$t-3, t-4$ & -0.04 & -0.06 & 0.01 & -0.33 & -0.16 & $-0.17^{* *}$ \\
\hline \multirow[t]{2}{*}{$t-4, t-5$} & -0.06 & -0.05 & -0.01 & -0.31 & -0.31 & -0.00 \\
\hline & \multicolumn{6}{|c|}{ Females } \\
\hline$t, t-1$ & 0.76 & 0.26 & $0.50 * * *$ & 0.56 & 0.32 & $0.24^{*}$ \\
\hline$t-1, t-2$ & 0.33 & 0.30 & 0.03 & 0.36 & 0.20 & 0.16 \\
\hline$t-2, t-3$ & 0.31 & 0.27 & 0.04 & 0.18 & 0.26 & -0.08 \\
\hline$t-3, t-4$ & 0.36 & 0.30 & $0.06^{* *}$ & 0.29 & 0.31 & -0.02 \\
\hline$t-4, t-5$ & 0.32 & 0.27 & 0.05 & 0.36 & 0.57 & $-0.21^{*}$ \\
\hline Obs. & 433,811 & 433,811 & - & 32,098 & 32,098 & - \\
\hline
\end{tabular}

Notes: West Germany 1980-2003, East Germany 1998-2003, private sector without agriculture and mining, establishments with one or more employees in $\mathrm{t}-5,{ }^{* * *} /\left.* *\right|^{*}$ indicates statistical significance at the $1 \% / 5 \% / 10 \%$ level. 
Table A4 Changes in the median age for exiting versus surviving establishments (absolute changes in years), matched sample, all establishments

\begin{tabular}{|c|c|c|c|c|c|c|}
\hline \multirow[t]{2}{*}{ Period } & \multicolumn{3}{|c|}{ West Germany } & \multicolumn{3}{|c|}{ East Germany } \\
\hline & Exits & Survivors & Difference & Exits & Survivors & Difference \\
\hline$t, t-1$ & 0.90 & 0.47 & $0.44^{* * *}$ & 0.73 & 0.60 & $0.14^{* * *}$ \\
\hline$t-1, t-2$ & 0.76 & 0.45 & $0.31 * * *$ & 0.73 & 0.55 & $0.18^{* * *}$ \\
\hline$t-2, t-3$ & 0.68 & 0.41 & $0.27 * * *$ & 0.67 & 0.48 & $0.19 * * *$ \\
\hline$t-3, t-4$ & 0.66 & 0.34 & $0.33 * * *$ & 0.57 & 0.42 & $0.15^{* * *}$ \\
\hline$t-4, t-5$ & 0.62 & 0.10 & $0.52 * * *$ & 0.58 & 0.17 & $0.40 * * *$ \\
\hline Obs. & 433,811 & 433,811 & - & 32,098 & 32,098 & - \\
\hline
\end{tabular}

Notes: West Germany 1980-2003, East Germany 1998-2003, private sector without agriculture and mining, establishments with one or more employees in $t-5, * * * / * / *$ indicates statistical significance at the $1 \% / 5 \% / 10 \%$ level. 